\title{
A new species of Omphalocyclus (Foraminiferida) from the Upper Cretaceous of Jamaica and its stratigraphical significance
}

\author{
GAVIN C. GUNTER, EDWARD ROBINSON \& SIMON F. MITCHELL \\ Department of Geography and Geology, University of the West Indies, Mona, Kingston 7, Jamaica
}

\begin{abstract}
The orbitoidal larger foraminifer Omphalocyclus maldonensis n. sp. is described from the Maldon Inlier of northwestern Jamaica, being the first record of this genus from the island. The limestone in which it occurs contains the Upper Cretaceous (Upper Maastrichtian) Titanosarcolites rudist fauna, together with larger foraminiferal specimens identified as Orbitoides megaloformis Papp \& Küpper. The new species differs from Omphalocyclus macroporus, the only other widely recognized species, in possessing a much smaller nucleus. At least some of the earlier records of Omphalocyclus from the Upper Cretaceous of Venezuela and Cuba should probably be referred to O. maldonensis. J. Micropalaeontol. 21(2): 149-153, December 2002.
\end{abstract}

\section{INTRODUCTION}

Larger foraminifera belonging to the Family Orbitoidae achieved circum-tropical distributions in the late Cretaceous (Dilley, 1973). Many of the species, particularly Orbitoides and Omphalocyclus have been used as biostratigraphic indicators in the platform limestone successions of the Mediteranean Tethys where ammonites and inoceramids are rare (e.g. Küpper, 1954; van Hinte, 1966; Dilley, 1973; Caus et al., 1996). Omphalocyclus has been widely recognized in Upper Cretaceous rocks in many parts of the Tethyan region, usually as $O$. macroporus (Lamarck) the type species (El-Asa'ad, 1989; Matsumaru, 1997). In most cases, the presence of Omphalocyclus has been used to indicate a Late Cretaceous, Maastrichtian, age for the rocks in which it occurs.

In the Caribbean, these foraminifera are also well known. Orbitoides is widespread (e.g. Renz, 1955; Seiglie \& Ayala-Castañares, 1963; Jiang \& Robinson, 1987), while Omphalocyclus has been reported from Cuba (Ellis, 1932; Rutten, 1935; Kupper, 1954; Seiglie \& Ayala-Castañares, 1963) and northern Venezuela (Renz, 1955).

During the course of re-mapping the Upper Cretaceous rocks of the Maldon Inlier, northwest Jamaica (Chubb, 1958; Meyerhoff \& Krieg, 1977; Fig. 1) two of us (GCG \& SFM) sampled a layer containing numerous specimens of the larger foraminiferal genus Omphalocyclus. This is the first record of this genus from Jamaica. However, the specimens from the Maldon Inlier differ from typical $O$. macroporus and are described herein as $O$. maldonensis. We further discuss the biostratigraphical significance of the orbitoidal foraminifera in the Caribbean.

\section{GEOLOGICAL SETTING}

Upper Cretaceous sedimentary rocks are well exposed in the Maldon Inlier in the Parish of St. James (western Jamaica: Fig. 1). The inlier has previously been mapped by Sawkins (1869), Bailey (Chubb, 1958) and Atkinson (1969). The succession, named informally by Chubb (1958), consists of two limestones, the Maldon Limestone and Vaughansfield Limestone, within a thick succession of volcaniclastic shales and sandstones (Fig. 2). These sediments were deposited in a shallow tropical sea, close to active volcanoes of a Cretaceous island-arc complex (Coates, 1977; Draper, 1987; Mitchell, in press). The limestones contain abundant rudist bivalves, including Titanosarcolites giganteus (Whitfield), Biradiolites jamaicensis Trechmann, Chiapasella sp., Antillocaprina spp., Thyrastylon spp., Bournonia spp. and Plagioptychus spp. (Chubb, 1971; Kauffman \& Sohl, 1974). This is a typical assemblage of the Titanosarcolites fauna (Chubb, 1971) and is traditionally considered to indicate a Maastrichtian age (Chubb, 1971; Sohl \& Kollman, 1985), although Jiang \& Robinson (1987) suggested it may also be partly Late Campanian. New strontium isotopic dates indicate a late Maastrichtian age (Steuber et al., 2002). Corals, gastropods and ostracodes are also present (Coates, 1977; Sohl \& Kollman, 1985; Hazel \& Kamiya, 1993; Sohl, 1998). The intervening clastics yield gastropods, corals, ostracodes and the larger foraminifera Kathina jamaicensis (Cushman \& Jarvis) and Ayalaina rutteni (Palmer) (Robinson, 1968; Atkinson, 1969; Hazel \& Kamiya, 1993). Hazel \& Kamiya (1993) erected three ostracode subzones in the Maldon Inlier. Zone 1a occurs in the Woodlands Shale, zone 1b in the Maldon Limestone and zone 1c in the upper Popkin Shale/lower Vaughansfield Limestone (Fig. 2).

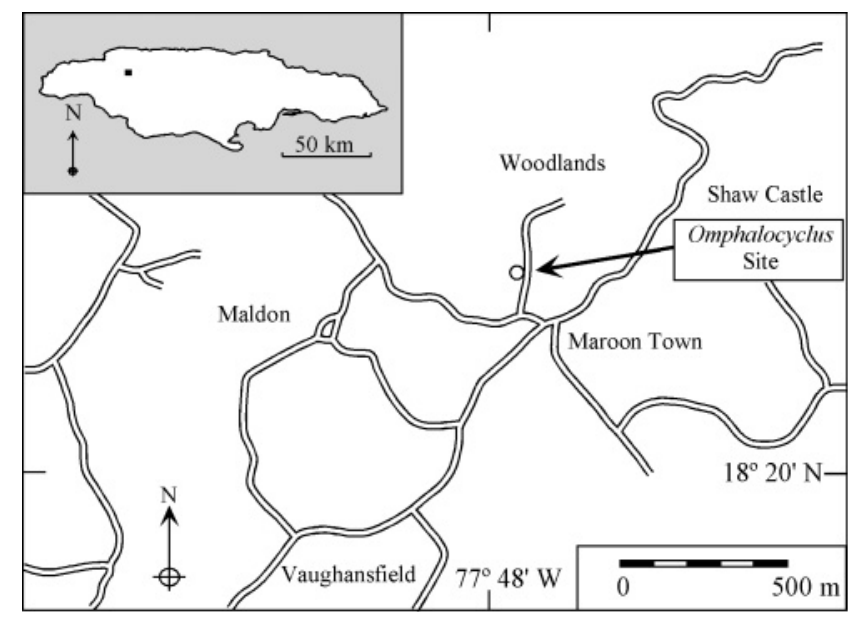

Fig. 1. Location of sample site in the Maldon Inlier (location in Jamaica inset). 


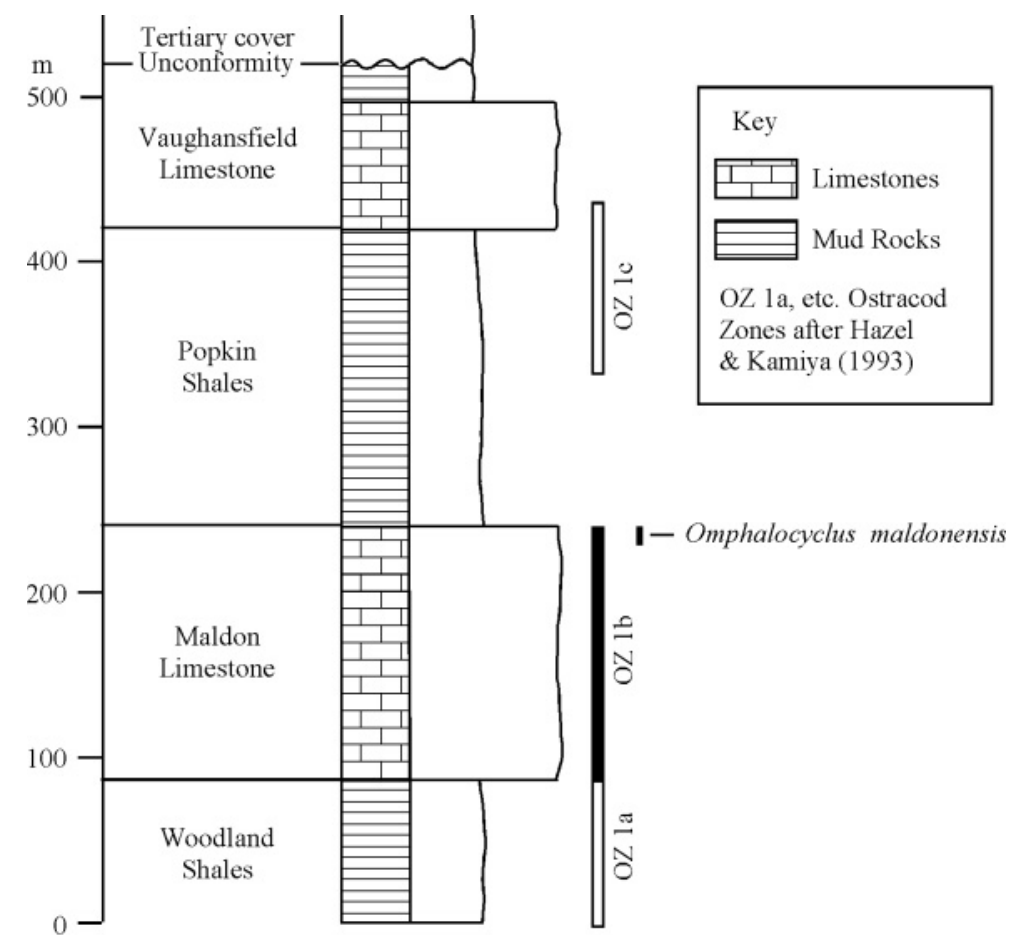

Fig. 2. Simplified geological succession in the Maldon Inlier.

\section{SYSTEMATIC PALAEONTOLOGY}

Order Foraminiferida Eichwald, 1830

Suborder Rotaliina Delage \& Herouard, 1896

Superfamily Orbitoidacea Schwager, 1876

Family Orbitoididae Schwager, 1876

Genus Omphalocyclus Bronn in Bronn \& Roemer, 1852

Omphalocyclus maldonensis $\mathrm{n}$. sp. (Pl. 1, figs 1-6)

? 1955 Omphalocyclus cf. macroporus Lamarck; Renz: pl. 5, figs 1-3, 5-6, ?figs 4, 10.

Type species. Orbulites macropora Lamarck, 1816.

Derivation. After the Maldon Inlier, where the species occurs.

Diagnosis. A species of Omphalocyclus with a quadrilocular nucleus with a diameter of $0.16 \mathrm{~mm}$ to $0.30 \mathrm{~mm}$, and a significant periembryonic zone of uniserial orbitoidal chambers.

Holotype. UWIGM RG2001.248.

\section{Paratypes. UWIGM1999.48-52.}

Material. About 200 complete tests from the Maldon Limestone, Maldon Inlier Jamaica (UWIGM 1999.45 \& UWIGM 1999.46). The tests are well preserved with good surface ornamentation.

Type locality and horizon. The specimens were collected c. $9 \mathrm{~m}$ below the top of the Maldon Limestone (Fig. 2), alongside a minor road c. $78 \mathrm{~m}$ north of the junction at Maroon Town, Parish of St James (Fig. 1). Omphalocyclus maldonensis occurs associated with the foraminifera Orbitoides megaloformis Papp \& Küpper (Pl. 1, fig. 7) and Kathina jamaicensis (Cushman \& Jarvis). Hazel \& Kamiya (1993) placed the Maldon Limestone within subzone $1 \mathrm{~b}$ of their informal ostracode zonation for the Titanosarcolites-bearing limestones and related sequences of Jamaica. Upper Maastrichtian (see discussion below).

Description. Externally the test is disk shaped, bilaterally depressed in the centre, more or less circular in outline. Many tests are asymmetrical, one side being flat to slightly depressed in the centre, the opposite side with a markedly depressed centre. Surface ornamented with a cellular pattern of low ridges mimicking the internal pattern of septa separating the chambers; periphery bluntly rounded, with two to three rows of coarse pores; smaller specimens with two rows of pores, frequently separated by a more or less prominent keel. Diameters of 176 measured specimens range from $1.2 \mathrm{~mm}$ to $6.6 \mathrm{~mm}$ and maximum thicknesses (at or near the periphery) from $0.24 \mathrm{~mm}$ to $0.98 \mathrm{~mm}$ (Fig. 3). Equatorial sections of well preserved megalospheric individuals exhibit a quadrilocular nucleus, similar in pattern to that of Orbitoides (e.g. Caus et al., 1996), surrounded by a thickened wall. Internal nuclear diameters of 11 sectioned individuals range from $0.16 \mathrm{~mm}$ to $0.30 \mathrm{~mm}$. Adauxiliary chambers (sensu Caus et al., 1996, p. 128) are generally 8 to 9 (observed range 6 to 10) in number, surrounded by about 7 or 8 cycles of orbitoidal chambers. In the outer part of the test, the equatorial layer consists of chambers with a more or less square cross-section (chessboard pattern of Höttinger, 1981).

In axial section, the nucleus is succeeded variably by 2 to 4 cycles of normal uniserial orbitoidal chambers, then by 5 to 
Upper Maastrichtian Omphalocyclus from Jamaica
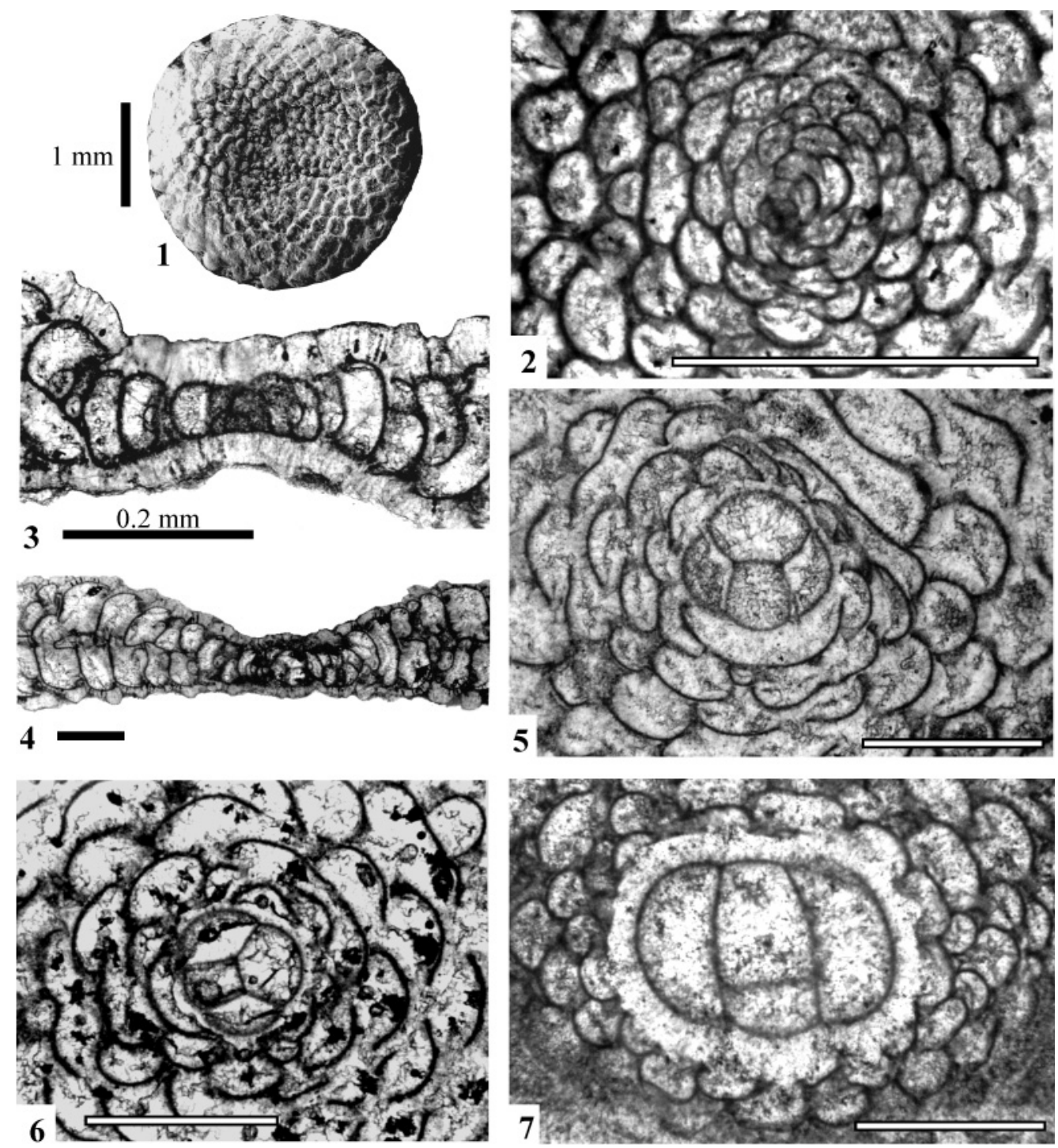

Explanation of Plate 1. figs 1-6. Omphalocyclus maldonensis sp. nov.: 1, holotype (UWIGM RG2001.248), scale bar 1 mm; 2, equatorial section of microspheric form (UWIGM1999.48); 3-4, transverse sections (UWIGM 1999.49-50); 5-6, equatorial section of macrospheric form (UWIGM1999.51-52). Scale bar for 2-6 is $0.2 \mathrm{~mm}$. fig. 7. Orbitoides megaloformis Papp \& Küpper. Equatorial section of macrospheric form (UWIGM1999.53), scale bar $0.2 \mathrm{~mm}$. All specimens from upper part of Maldon Limestone.

10 cycles of biserial orbitoidal chambers of the type illustrated by Höttinger (1981, fig. 7); a third, somewhat irregular layer of equatorial chambers is inserted between the last 3 to 6 cycles of orbitoidal chambers in the peripheral region. These are of the kind described by Höttinger (1981, figs 5 \& 6). The more numerous triserial cycles are seen preferentially in microspheric specimens. No lateral chambers of the orbitoidal kind are present.

Equatorial sections of the microspheric generation show a tiny, apparently biserial embryonic stage, surrounded by a low trochospiral coil of about 6 to 8 chambers. These are succeeded in turn by from five to as many as 12 or more cycles of orbitoidal equatorial chambers, similar to those of the megalospheric generation. These may be followed, in the distal part of the test, by several cycles of chambers of the chessboard pattern of Höttinger (1981).
Dimensions. Measurements of the nucleus of specimens of Omphalocyclus from Jamaica and The Netherlands (early late Maastrichtian, ENCI quarry) is given below. The terminology, $\mathrm{Li}$ and li, follows that used by van Hinte (1966) for the nucleus of Orbitoides and is illustrated with reference to Figure 4. Measurements in $\mathrm{mm}$.

\begin{tabular}{lrcccccccc}
\hline Locality & \multirow{2}{*}{$n$} & \multicolumn{4}{c}{ Li } & \multicolumn{4}{c}{ li } \\
& & Mean & SD & Min & Max & Mean & SD & Min & Max \\
\hline Jamaica & 11 & 0.23 & 0.04 & 0.30 & 0.16 & 0.23 & 0.03 & 0.28 & 0.19 \\
ENCI & 9 & 0.42 & 0.08 & 0.49 & 0.27 & 0.43 & 0.08 & 0.54 & 0.30 \\
\hline
\end{tabular}

Remarks. Omphalocyclus maldonensis differs from typical $O$. macroporus in possessing a smaller nucleus, in exhibiting a 

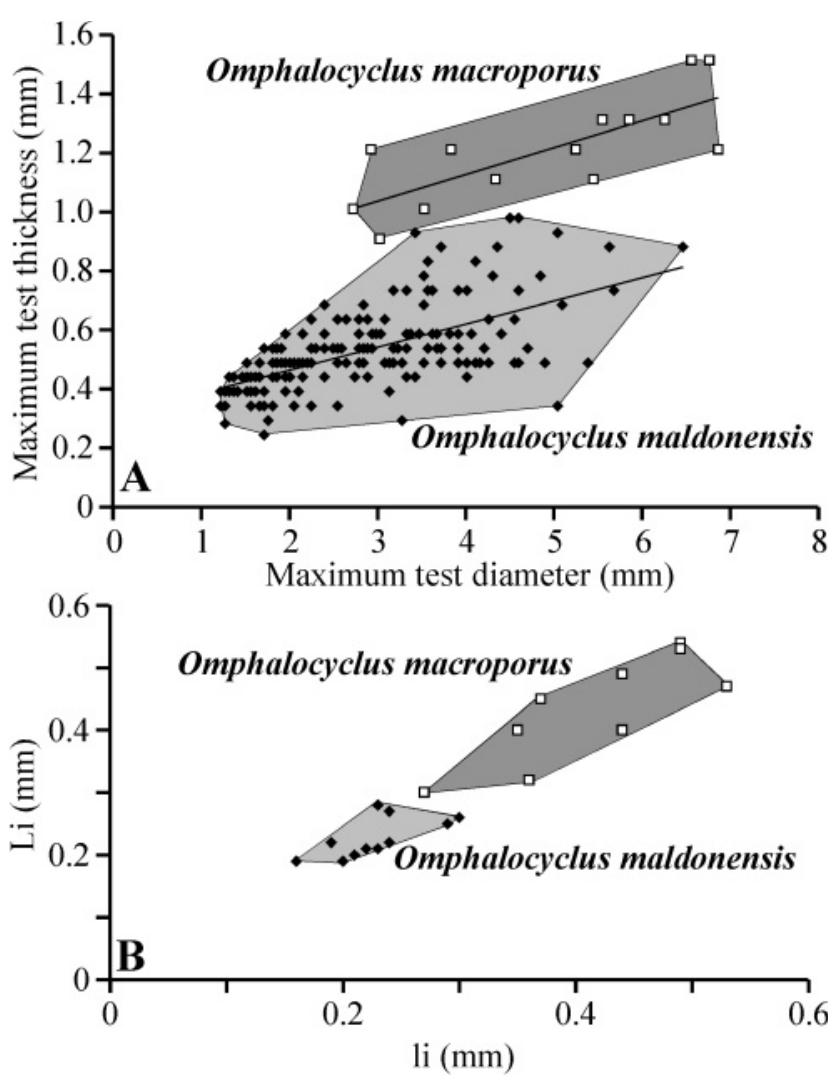

Fig. 3. Scatter plots of maximum test thickness versus maximum test diameter and $\mathrm{Li}$ versus $\mathrm{li}$ for Omphalocyclus macroporus and O. maldonensis.

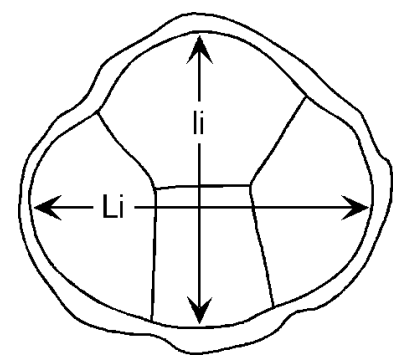

Fig. 4. Details of measurements ( $\mathrm{Li} \& \mathrm{li}$ ) of nuclear dimensions in Omphalocyclus.

significant periembryonic zone of uniserial orbitoidal chambers, and in having a less pronounced surface ornamentation. It differs from $O$. schlumbergeri (Silvestri) in possessing a quadrilocular nucleus. It is distinguished from Pseudomphalocyclus blumenthali Meric by the lack of lateral chambers of the orbitoidal (or any other) type. Renz (1955) described specimens of $O$. cf. macroporus (Lamarck) from Venezuela that included a range of $0.25 \mathrm{~mm}$ to $0.3 \mathrm{~mm}$ for the nuclear diameter and the presence of uniserial chamber layers surrounding the nucleus, suggesting a close relationship with $O$. maldonensis. Lamarck (1816) did not state a type locality for O. macroporus. However, since Defrance (1825) it has generally been regarded as 'Pietersberg', near Maastricht, The Netherlands (Van Gorsel, 1978). Sample ER1598, collected by one of us (ER) from near the base of unit Md of the Maastrichtian section at the ENCI quarry at Pietersberg, yielded megalospheric specimens of $O$. macroporus with nuclear dimensions ranging from about $0.3 \mathrm{~mm}$ (one specimen only) to $0.55 \mathrm{~mm}$, roughly twice the size of $O$. maldonensis (Fig. 4). In this study, the maximum diameter (at or near the periphery) and maximum thickness of 176 specimens of $O$. maldonensis were measured. For comparison, the same dimensions of 14 specimens from sample ER1598 were also measured. Both populations are clearly distinct (Fig. 3).

\section{SIGNIFICANCE OF OMPHALOCYCLUS MALDONENSIS}

In the upper part of the Maldon Limestone, O. maldonensis occurs with rare specimens of Orbitoides. Equatorial thin sections of these Orbitoides (Pl. 1, fig. 7) are comparable with examples of Orbitoides megaloformis collected from the Guinea Corn Formation at Logie Green (e.g. Krijnen et al., 1993, figs 22-6,7) in the Central Inlier (central Jamaica: Fig. 1). Van Hinte (1966) demonstrated that within the Orbitoides lineage there is an increase in the size of the nucleus and number of epi-auxillary chamberlets as one passes from more primitive to more advanced species through the late Cretaceous. Based on the nuclear characteristics, Jiang \& Robinson (1987, fig. 8) suggested that the Logie Green Orbitoides might indicate a stratigraphic position near the Campanian-Maastrichtian boundary. Krijnen et al. (1993) noted that the specimens of O. megaloformis from the Central Inlier partly fit the limits set by Van Hinte (1966) for that taxon and suggested that the fauna might be slightly more advanced and, therefore, represented the very Early Maastrichtian. Caus et al. (1996), in a review of the biostratigraphic value of species of the genus Orbitoides, proposed that Orbitoides megaloformis Papp \& Küpper characterized the latest Campanian of Europe. Independent age dating of the Logie Green site comes from nannofossils (Robinson, 1988, p. 59). The site has yielded a flora that includes Lithraphidites praequadratus Roth, but lacks L. quadratus Bramlette \& Martini, Quadrum trifidum (Stradner) and Reinhardtites levis Prins \& Sissingh. This indicates zone CC25A (Sissingh, 1977), which Hardenbol et al. (1998) suggest is of latest Early to early Late Maastrichtian age in the Tethys. New strontium isotopic dates derived from well-preserved skeletal calcite of rudist shells from the Maldon Limestone indicate a latest Maastrichtian age (65 to 65.83 Ma: Steuber et al., 2002).

Renz (1955, pp. 59-60) reported O. cf. macroporus and Orbitoides palmeri Gravel from Venezuela. The nuclear dimensions and presence of uniserial chamber layers surrounding the nucleus in $O$. cf. macroporus suggest it may represent $O$. maldonensis. The quoted dimensions of the nucleus for $O$. palmeri $(508 \mu \mathrm{m} \times 381 \mu \mathrm{m})$ and its distinctly quadrilocular nucleus (Renz, 1955, pl. 6, fig. 3) suggest that this designation may be a synonym of $O$. megaloformis. Examination of the specimens, however, would be required to confirm these interpretations. It is, therefore, possible that this Venezuelan fauna contains the same assemblage of orbitoid foraminifera as the upper Maldon Limestone. Renz (1955) considered that his unit bearing $O$. cf. macroporus and $O$. palmeri was Maastrichtian, based on the presence of Vaughanina Palmer, Omphalocyclus Bronn and Sulcoperculina Thalmann.

In the type Maastrichtian in The Netherlands, O. macroporus is associated with $O$. apiculata Schlumberger (Hardenbol et al., 1998). This association has also been reported from elsewhere, 
including Saudi Arabia (El-Asa'ad, 1989), Turkey (Matsumaru, 1997) and, significantly, Cuba (Seiglie \& Ayala-Castañares, 1963). Hardenbol et al. (1998) indicated that O. macroporus appeared in the upper Lower Maastrichtian.

In the Caribbean, therefore, there appear to be two orbitoid faunas, a fauna with $O$. megaloformis and $O$. maldonensis (Jamaica and possibly northern Venezuela); and a fauna with O. apiculata and O. macropora (Cuba).

\section{ACKNOWLEDGEMENTS}

Thanks to the Electron Microscope Unit, UWI, for SEM analysis. We thank the reviewers (L. Höttinger and one anonymous) and the editor (Malcolm Hart) for their comments on this paper.

\section{Manuscript received 11 March 2002 Manuscript accepted 10 July 2002}

\section{REFERENCES}

Atkinson, T.C. 1969. The Geology of the country around Maldon and Maroon Town, St. James, Jamaica. Journal of the British Speleological Association, 6: 90-94.

Bronn, H.G. \& Roemer, C.F. 1852. Lethaea Geognostica; Vierte Periode; Kreide-Gebirge ed. 3, 2, pt 5: 81-96.

Caus, E., Bernaus, J.M. \& Gomez-Garrido, A. 1996. Biostratigraphic utility of species of the genus Orbitoides. Journal of Foraminiferal Research, 26: 124-136.

Chubb, L.J. 1958. The Cretaceous rocks of central St James. Geonotes, 1: $3-11$.

Chubb, L.J. 1971. Rudists of Jamaica. Palaeontographica Americana, 7(45): $1-257$

Coates, A.G. 1977. Jamaican coral-rudist frameworks and their geologic setting. In: Frost, S.H., Weiss, M.P. \& Saunders, J.B. (Eds), Reefs and related carbonates - ecology and sedimentology. AAPG Studies in Geology, 4: 83-91.

Defrance, M.J.L. 1825. Mineralogie et Geòlogie. Dictionaire des Sciences Naturelles, 26. F.G. Levrault, Paris, 1-555.

Delage, Y. \& Herouard, E. 1896. Traité de Zoologie Concrète. Tome I. La Cellule et les Protozoaires. Schleicher Frères, Paris, 1-584.

Dilley, F.C. 1973. Cretaceous larger foraminifera. In: Hallam, A. (Ed.), Atlas of Palaeobiogeography: 403-419.

Draper, G. 1987. A revised tectonic model for the evolution of Jamaica. In: Ahmad, R. (Ed.), Proceedings of a workshop on the status of Jamaican geology. Geological Society of Jamaica, Special Issue: $120-150$.

Eichwald, C.E. von 1830. Zoologia specialis, 2. D.E. Eichwaldus, Vilnae, $1-323$.

El-Asa'ad, G.M.A. 1989. Loftusia arabica sp. nov. (Foraminiferida) from the Maastrichtian of central Saudi Arabia. Journal of Micropalaeontology, 8: 49-54.

Ellis, B.F. 1932. Gallowayina browni, a new genus and species from Cuba, with notes on the American occurrence of Omphalocyclus macroporus. American Museum of Natural History, Novitates, 568: 5-8.

Hardenbol, J., Thierry, J., Farley, M.B., Jacquin, T., De Gracianskty, P.-C. \& Vail, P.R. 1998. Chart 5. Cretaceous biochronostratigraphy. In: De Graciansky, P.-C., Hardenbol, J., Jacquin, Th. \& Vail, P.R. (Eds), Mesozoic and Cenozoic sequence stratigraphy of European basins. SEPM Special Publication, 60.

Hazel, J.E. \& Kamiya, T. 1993. Ostracode biostratigraphy of the Titanosarcolites-bearing limestones and related sequences of Jamaica. In: Wright, R.M. \& Robinson, E. (Eds), Biostratigraphy of Jamaica. Geological Society of America Memoir, 182: 65-91.
Höttinger, L. 1981. Fonctions de la disposition alternante des loges chez les foraminifères et la structure d' Omphalocyclus. Cahiers de Micropaléontologie, 4: 45-54.

Jiang, M.-J. \& Robinson, E. 1987. Calcareous nannofossils and larger foraminifera in Jamaican rocks of Cretaceous to early Eocene age. In: Ahmad, R. (Ed.), Proceedings of a workshop on the status of Jamaican geology. Geological Society of Jamaica, Special issue: 24-51.

Kauffman, E.G. \& Sohl, N.F. 1974. Structure and evolution of Antillean Cretaceous rudist frameworks. Verhandlungen Naturforschened Gesellschaft, 84: 399-467.

Krijnen, J.P., MacGillavry, H.J. \& van Dommelen, H. 1993. Review of Upper Cretaceous orbitoid larger foraminifera from Jamaica, West Indies, and their connection with rudist assemblages. In: Wright, R.M. \& Robinson, E. (Eds), Biostratigraphy of Jamaica. Geological Society of America, Memoir, 182: 29-63.

Küpper, K. 1954. Notes on Upper Cretaceous larger foraminifera II, genera of the Subfamily Orbitoidinae with remarks on the microspheric generation of Orbitoides and Omphalocyclus. Contributions to the Cushman Foundation for Foraminiferal Research, 5: 179-184.

Lamarck, J.B. 1816. Histoire Naturelle des Animaux sans Vertèbres, 2. Verdière, Paris, 1-568.

Matsumaru, K. 1997. On Pseudorbitoides trechmani Douvile (Orbitoidal Foraminifera) from Turkey. Revue de Micropaleontologie, 40: $339-346$.

Meyerhoff, A.A. \& Krieg, E.A. 1977. Petroleum potential of Jamaica. Ministry of Mining and Natural Resources, Government of Jamaica, $1-131$.

Mitchell, S.F. in press. Sedimentary and tectonic evolution of central Jamaica. In: Bartolini, C. (Ed.), The circum-Gulf of Mexico and Caribbean region: plate tectonics, basin formation and hydrocarbon habitats. American Association of Petroleum Geologists Memoir

Renz, H.H. 1955. Some Upper Cretaceous and lower Tertiary foraminifera from Arugua and Guarico Venezuela. Micropalaeontology, 1: 52-71.

Robinson, E. 1968. Chubbina, a new Cretaceous alveolinid genus from Jamaica and Mexico. Palaeontontology, 2: 56-534.

Robinson, E. 1988 (for 1987). Field Guide. Late Cretaceous and early Tertiary sedimentary rocks of the Central Inlier. Journal of the Geological Society of Jamaica, 24: 49-67.

Rutten, M.G. 1935. Larger foraminifera of northern Santa Clara Province, Cuba. Journal of Paleontology, 9: 527-545.

Sawkins, J.G. 1869. Reports on the geology of Jamaica, with an appendix on the palaeontology of the Caribbean by R. Etheridge. Memoirs of the Geological Survey of Great Britain: 1-399.

Schwager, C. 1876. Saggio di una classificazione dei Foraminiferi avuto riguardo alle loro famiglie naturali. Bolletino R. Comitato Geologico d'Italia, 7: 475-485.

Seiglie, G.A. \& Ayala-Castañares, A. 1963. Sistematica y bioestratigrafia de los Foramiferos grandes del Cretacico superior (Campaniano y Maestrichtiano) de Cuba. Paleontologica Mexicana, 13: 3-40.

Sissingh, W. 1977. Biostratigraphy of Cretaceous calcareous nannoplankton. Geologie et Mijnbouw, 56: 335-350.

Sohl, N.F. 1998. Upper Cretaceous Trochacean gastropods from Puerto Rico and Jamaica. Palaeontographica Americana, 60: 1-109.

Sohl, N.F. \& Kollman, H.A. 1985. Cretaceous actaeonellid gastropods from the Western hemisphere. US Geological survey professional papers, 1304: 1-104.

Steuber, T., Mitchell, S.F., Buhl, D., Gunter, G. \& Kasper, H.U. 2002. Catastrophic extinction of Caribbean rudist bivalves at the Cretaceous-Tertiary boundary. Geology, 30: 999-1002.

Van Gorsel, J.T. 1978. Late Cretaceous orbitoidal foraminifera. In: Hedley, R.H. \& Adams, C.G. (Eds), Foraminifera, 3. Academic Press, London, 1-120.

van Hinte, J.E. 1966. Orbitoides from the Campanian type section. Koninklijke Nederlandes Akademie van Wetenschappen, Proceedings Serie B, 69: 79-110. 